instance, have not yet started; the Soviet Union has only just published its national programme. This was one of the policy themes under discussion at the annual IBP General Assembly and meeting of the Special Committee for IBP (SCIBP) held this April at Varna on the Black Sea coast of Bulgaria. It is now "as clear as a bell" according to the IBP Scientific Director, Dr E. B. Worthington, that much IBP work cannot be finished by the end of 1972 . There must be a mechanism for checking progress and for continuing the promising work after that time. Even more important is a mechanism for closing down the unpromising activity, but this is now in hand. Plans are being made for assessing the work of each of the seven sections into which IBP research is organized and for evaluating themes within the sections. Before the conference an index to IBP projects was abstracted by the central office from the thirty-odd national programmes so far available. 1,400 projects are identified in this document. They are classified under subject, section and the scientist responsible for them.

The Eastern Europe venue for the meeting proved encouraging not only for Russian participation but also to scientists of the other socialist countries, who have lacked not enthusiasm but mobility in previous years. A curious situation emerged at the meeting. Although ecological science appropriate to IBP is at a high level in the Eastern European countries, there is little co-operation between the different national workers. It has needed an IBP to bring them together. For instance, on the Lower Danube the com. mercially valuable fisheries and vegetation are extensively studied by the scientists of Rumania and Bulgaria for which the river forms a common border, but up till now they have not shared their results or co-ordinated their activities.

Soviet authorities have paid lip service to IBP, but they have not played much part in the international planning and preparations. Things are now on a much better footing. Quite a large Soviet contingent was present at Varna. Their long awaited programme was available-well produced and in English. The newly appointed secretary of the national committee proved to be a professor of zoology at Leningrad University of great energy and with an excellent command of English. At the meeting a very distinguished Soviet limnologist, Professor Winberg, accepted the vacant post of convener for the Freshwater Productivity section (PF) from the retiring American. Two major international scientific conferences on IBP themes are to be held in the Soviet Union this year; one on plant root systems at the end of the summer and the other, on the place of bacteria in freshwater productivity, in the winter. Russian scientists have made both subjects peculiarly their own.

Improved relations in another important sector are reported from the conference. FAO (the UN Food and Agriculture Organization) is showing a much changed attitude towards IBP since the appointment of the new Director-General, Dr A. H. Boerma. Lengthy discussions held recently between IBP Central Office staff and all FAO departments have led to the intention to make much departmental work available to the programme.

Shortage of funds continue to hamstring IBP activities centrally as well as at the national programme level. The meeting passed a resolution to be forwarded to the parent body, ICSU, to raise the national subscriptions for the coming year. These are on a three-tier basis, and on the new tariff the highest subscription will be $\$ 25,000$ instead of $\$ 10,000$ and the lowest $\$ 250$ instead of $\$ 100$. But this will not help the running expenses for this year.

\section{New Council for Nature}

THe argument which has sprung up over the control of the Council for Nature concerns the new constitution which was adopted at the extraordinary general meeting on April 20. Since its foundation in 1959, to co-ordinate at a national level the views and opinions of unofficial bodies concerned with conservation and natural history, the Council for Nature has had an executive committee elected from among its member bodies, of which there are now 450 . Of these, the museums and universities had one representative each, and there are several representatives from national and local natural history societies and conservation organizations. There are also eight places filled by experts in various aspects of natural history, nominated by the executive committee itself to ensure that important sections of nature were not overlooked in the council's activities. At a general meeting in 1967, it was decided that these eight members should be nominated by national societies and not appointed by the executive committee.

Under the new constitution, the executive committee is replaced by a council with members appointed by other bodies. Four members will be appointed by the Royal Society for the Protection of Birds and four by the Society for the Promotion of Nature Reserves and its County Naturalists' Trusts Committee. A Natural History Societies' Committee, to be set up by the council and to consist of representatives of national, regional and local affiliated bodies particularly concerned with natural history, will also appoint four members to the council. The Fauna Preservation Society will appoint two members and the rest will be appointed one each by nine other organizations including the Scottish Wildlife Trust, the Field Studies Council, the Linnean Society, the Botanical Society of the British Isles and the Museums Association.

These changes are regarded by the Council for Nature as a necessary step towards closer co-ordination with other voluntary bodies concerned with conservation. The old executive committee, when recommending the changes, advised that "to avoid overlapping of function, it is advisable that the Council for Nature should neither appear to be, nor act like, a society in its own right".

The work of the council will continue to involve national co-ordination and promotion of ideas and activities concerned with natural history and conservation. The latest report of the council, entitled Working for Nature, records the council's role in promoting in Parliament bills concerned with the countryside, the protection of wild plants and the conservation of seals. The Conscrvation Corps, with about 13,500 available volunteers, has continued its various field activities such as laying hedges, making nature trails and generally helping to manage the countryside. The local member bodies have continued to receive information and advice from the council, which admits 
that it is concerned that these bodies subscribe only three per cent of its annual income, which comes mostly from national sources.

\section{Power Politics}

THE row over British fuel policy, which started as a general rumble of discontent, has recently become more shrill. The opponents of the Government's policies have found a focus for their irritation-at Seaton Carew, in County Durham, where the Central Electricity Generating Board wants to build a power station. So far, the choice of fuel for the station has not been decided, and it looks as if the supporters of coal intend to make a test case of it. Seaton Carew is in the heart of a mining area, and the coal lobby, led by Lord Robens of the National Coal Board, and ably supported by a band of mining Members of Parliament, is determined that Seaton Carew power station will burn nothing but coal.

The result of this may be that the station will not be built at all. The CEGB is determined to build a nuclear station at Seaton Carew, almost certainly an advanced gas cooled reactor, and is not willing to consider anything else. If it is balked, its reaction will be to cancel the station altogether and go ahead with an advanced gas cooled reactor at Heysham, in the north-west, where the problems of coal are not so keenly felt. Ironically, the rationale for this may have been supplied by Lord Robens himself, by his offers of coal at knock-down prices to the aluminium smelters. It now seems likely that three smelters will be built; Rio Tinto Zinc will build one in Anglesey, British Aluminium will get a site at Invergordon, and Alcan will be offered a site in the north-east, near Blythe. Lord Robens has already promised Alcan coal at cheap rates (probably $3 \cdot 25 d$. per therm), and the original intention was to ship the coal from the north-east to Invergordon. Spared of the need to ship the coal, the Coal Board should be able to offer even more competitive rates for a smelter in Northumberland. This would take the edge off the argument about Seaton Carew, and any surplus electricity at Blythe could be exported to the national grid, thereby further reducing the need for the Seaton Carew station.

In fact the CEGB could well do without a new power station. After two mild winters, and an industrial recession which has reduced the growth of electricity consumption, it is almost embarrassed by its excess capacity. Power stations, of course, take a long time to build, and by the time any power station started now was finished, the situation could be very different. Optimists believe that when the current recession ends, the growth of electricity consumption will return to traditional rates. In the meantime, however, it would be quite possible for the CEGB to delay starting new stations for a little while without putting itself in any danger.

\section{Launching Ships}

LLOYD's Register of Shipping has been asked by the shipbuilding industry to look into the problems of launching very large ships, especially the new generation of oil tankers, because of the damage which may be sustained by a large ship as it is launched down a slipway. The chief ship surveyor of Lloyd's Register,
Mr Jack Roberts, points out that this is an old problem; the new factor is the advent of very large ships, which means that damage sustained during launching can be costly to put right.

One of the factors involved is that during the launching of a ship down a slipway the after end is partially waterborne and there are supports at the bows, but the middle of the ship may not be supported at all. Another problem is connected with structures known as "ways" which are attached to the hull in the shipyard. When a ship is launched, the temporary ways fixed to the hull slide over broad longitudinal surfaces on the slipway, so that the ways do the sliding rather than the ship. The trouble is that the pressure of the ways on the ship during launching can lead to buckling of the hull.

The trend toward the building of ships in dry docks, so that when the hull is finished the dock is flooded and the ship floated out, surmounts the problems associated with slipway launchings. Alternatively, large ships can be launched in two halves. Ships built to pass the assessment of classification societies such as Lloyd's are inherently strong enough to survive the launching process without damage, however, so British shipyards are unlikely to have to invest in costly building docks. For example, Swan Hunter, the Tyneside shipbuilders, plan to launch two 240,000 ton tankers on order for Esso down slipways.

According to Mr Roberts, Lloyd's are unlikely to make rules for the launching of ships, because there are so many factors involved. It is more likely that Lloyd's will simply advise the industry on launching procedures.

\section{Astronomy in Scotland}

THE Royal Observatory in Scotland is celebrating 150 years of Scottish astronomy. A brief ceremony to mark the occasion, attended by the provost and by a number of astronomers working in Scotland, was held in the observatory on April 25.

Astronomy in Scotland got under way in the early years of the nineteenth century, chiefly because of the influence of the Astronomical Institute of Edinburgh. This society decided to build a scientific observatory in Edinburgh, which was started 150 years ago in 1818 , and finished six years later. This was the main building of the observatory on Calton Hill, still a familiar landmark in the centre of Edinburgh. Because of the cost of building and equipping the observatory, the society ran into financial difficulties. It was unable to afford the staff to run the observatory and to produce the star catalogue-the chief project of the society at the time.

The city authorities and the university were approached for help. The society suggested that the professor of practical astronomy in the university should be appointed to run the observatory and it put forward the title "Astronomer Royal for Scotland". Until then the professorship had been a sinecure, because there were no astronomical instruments in the university. The first Astronomer Royal for Scotland was Thomas Henderson, the only Scot to have held the post. Professor H. A. Brück, professor of astronomy in Edinburgh university, holds the title at present.

The observatory was handed over to the Government in 1847 to become the Royal Observatory of Scotland. In 1895 the Royal Observatory moved to its present 